\title{
Phyto-oestrogens: do they have a role in breast cancer therapy?
}

\author{
S. Ramnarine ${ }^{1}$ J. MacCallum ${ }^{2}$ and M. Ritchie ${ }^{2}$ \\ ${ }^{1}$ Edinburgh University, Edinburgh, UK and ${ }^{2}$ Napier University, Edinburgh, UK
}

Breast cancer is the most common malignancy in women ${ }^{(1)}$. Each year 44335 women living in the UK are diagnosed with breast cancer ${ }^{(2)}$. Female sex hormones, such as oestrogen, are clearly implicated in breast cancer and conventional treatments include manipulation of the hormonal environment. There is both epidemiological ${ }^{(3,4)}$ and experimental ${ }^{(5)}$ evidence that plant oestrogens (phyto-oestrogens) in the diet may alter oestrogen metabolism, but the potential role of phyto-oestrogens in the management of breast cancer is unknown.

Ethnobotantical information has provided evidence of a potential anti-cancer effect of Kwai Krua root, Pueraria Mirifica (PM) ${ }^{(6,7)}$, a herb commonly used in Thailand for enhancing female health. The herb contains a mixture of phyto-oestrogens including genistein (GEN), daidzein (DAI) and miroestrol. The aim of the present study was to evaluate the possible role of phyto-oestrogens, in particular those present in PM, in the management of breast cancer. The investigation was carried out using an in vitro model that included: powdered extract of PM (concentrations ranging from $0.1 \mu \mathrm{g} / \mathrm{ml}$ to $1000 \mu \mathrm{g} / \mathrm{ml}$ ); $\beta$-oestradiol ( $\beta \mathrm{E}$; concentrations $10^{-2} \mathrm{M}-10^{-6} \mathrm{M}$ ); GEN (concentrations $10^{-8} \mathrm{M}-10^{-4} \mathrm{M}$ ); DAI (concentrations $10^{-8} \mathrm{M}-10^{-4} \mathrm{M}$ ); $\mathrm{MCF}-7$ oestrogen receptor (ER)-positive breast cancer cell line (ATCC HTB-22). The effect of phyto-oestrogen exposure on cell growth over time was also monitored.

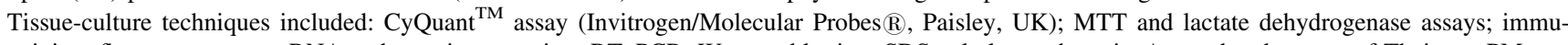
nostaining; flow cytometry; mRNA and protein extraction; RT-PCR; Western blotting; SDS gel electrophoresis. A powdered extract of Thai root PM was prepared at a stock concentration of $10 \mathrm{mg} / \mathrm{ml}$ in dimethyl sulfoxide and diluted in medium to various concentrations for use. $\beta \mathrm{E}$, daidzein and GEN were prepared at stock concentrations in dimethyl sulfoxide and diluted as appropriate. MCF-7 ER-positive cells were maintained in culture for use.

Initial results indicated that ER $\alpha$ :ER $\beta$ mRNA expression appeared to change over time $(0.5-24 \mathrm{~h})$, suggesting a possible modulation of the receptors occurring at the level of the mRNA. This effect was particularly notable over the range of PM concentrations. GEN also produced similar effects on mRNA levels. Cell-growth studies over $4 \mathrm{~d}$, as examined using the CyQuant ${ }^{\mathrm{TM}}$ assay, indicated low growth rates for the PM-treated cells (especially at $10 \mu \mathrm{g} / \mathrm{ml}$ ) with an increasing effect over time that appeared to reach significance $(n 4$; ANOVA; $P=0.038)$ by day 3 or 4 when compared with untreated cells.

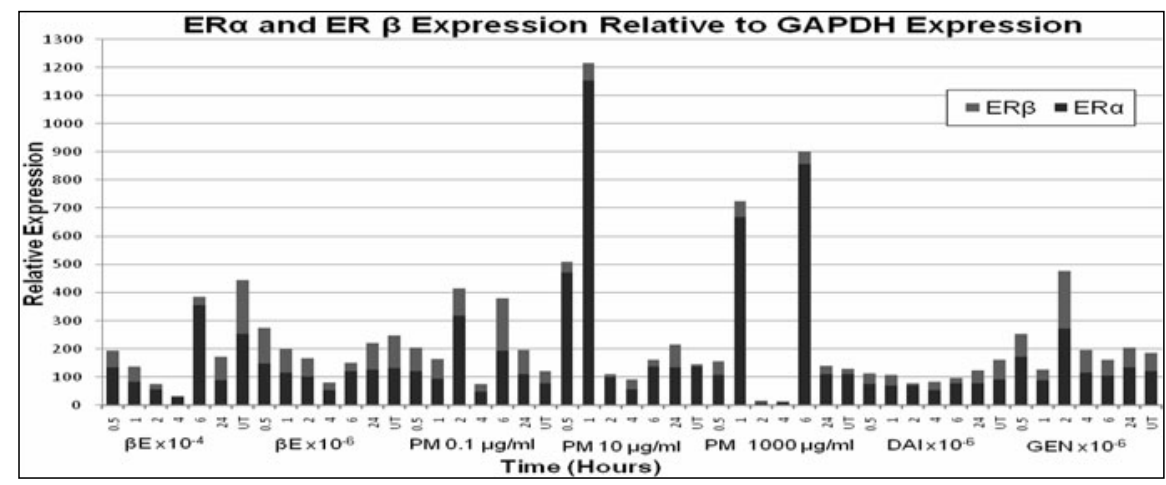

Fig. 1. For each treatment expression of ER $\alpha$ and ER $\beta$ mRNA is shown. Time points used were $0.5,1,2,4,6$, and $24 \mathrm{~h}$. Expression of ER $\alpha$ is higher for PM treatments $(10$ and $1000 \mu \mathrm{g} / \mathrm{ml}$ ); PM at $0.1 \mu \mathrm{g} / \mathrm{ml}$ is in line with $\beta \mathrm{E}$ and GEN. Expression of ER $\beta$ is decreased for PM at 10 and $1000 \mu \mathrm{g} / \mathrm{ml}$, and similar to BE and GEN for PM at $0.1 \mu \mathrm{g} / \mathrm{ml}$. GAPDH, glyceraldehyde-3-phosphate dehydrogenase.

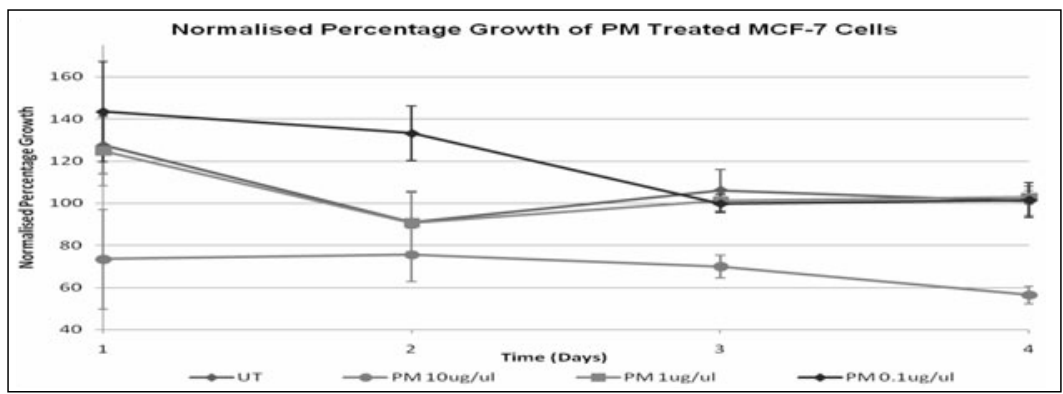

Fig. 2. Effects of PM on MCF-7 growth over $4 \mathrm{~d}$. The maximum concentration used was $10 \mu \mathrm{g} / \mathrm{ml}$, as higher concentrations were previously found to be directly toxic to the cells. Reduction in growth was significant $(P<0.05)$ for PM at $0.1 \mu \mathrm{g} / \mathrm{ul}$ over $4 \mathrm{~d}$.

These preliminary results are indicative of a potential anti-cancer action of PM that may be of use in the treatment of breast cancer. Further studies are required to confirm this possibility.

This study was funded by Solgar USA, Bio-Botanica and Smith Naturals. The MCF-7 ER-positive cells were a gift from CRUK.

1. National Breast Cancer Foundation Inc (2007) What is breast cancer? http://www.nationalbreastcancer.org/About-Breast-Cancer/What-Is-Breast-Cancer/

2. Cancer Research UK (2007) UK breast cancer incidence. http://info.cancerresearchuk.org/cancerstats/types/breast/incidence/

3. Wu AH \& Pike MC (1995) Am J Clin Nutr 62, 151-153.

4. Granata OM, Traina A, Ramirez S et al. (2009) Ann N Y Acad Sci 1155, 232-236.

5. Richter DU, Mylonas I, Toth B et al. (2009) Gynecol Endocrinol 25, 32-38.

6. Chirawatkul S, Patanasri K \& Koochaiyasit C (2002) Nurs Health Sci 4, 113-121.

7. Trisomboon H, Malaivijitnond S, Suzuki J et al. (2004) J Reprod Dev 50, 639-645. 